\title{
The physiological bases of nutrient responses; growth and fattening
}

\author{
By G. E. LOBLEY, Rowett Research Institute, Bucksburn, Aberdeen $A B 29 S B$
}

The ruminant nutritionist strives to understand, through a sound knowledge of digestion and metabolism, how animals will respond to different feeds and intakes, with the intention to manipulate diets or physiological mechanisms to improve productive performance. The present practical feeding schemes (e.g. Agricultural Research Council, 1980) are based predominantly on empirical input-output information but present research trends are towards the development of dynamic models based on metabolic interactions. Attainment of this goal is some way in the future but in the present paper it is intended to indentify some of the important areas where our understanding needs to be clarified or extended. Protein metabolism, allied with skeletal development, is the major determinant of body growth and this will provide the main theme but the important area of protein-energy interactions will also be highlighted.

\section{Amino acid supply}

Nitrogen interconversions in the forestomach. A prerequisite to any understanding of metabolic control functions is a knowledge of the amounts of dietary nutrients available to the animal. When considering protein metabolism of the simple-stomached animal, net dietary amino acid uptake can be determined fairly easily and accurately as the difference between the amounts supplied in the feed and the flow at the terminal ileum. Unfortunately for ruminants such a procedure is inadequate because complex interconversions occur, under the influence of the rumen microflora, between dietary, endogenous and microbial $\mathrm{N}$ sources which can result in either net loss or gain of material across the forestomach. Such interactions are influenced by several factors including the physico-chemical nature of the ration and protein:energy available to the microbes. Thus, for example, the

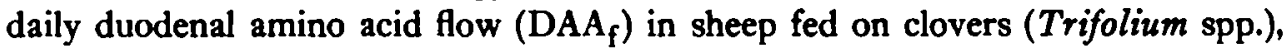
processed in different ways but supplying similar amounts of dietary amino acids $\left(123^{-127} \mathrm{~g} / \mathrm{d}\right)$, can be very different. On fresh clover the $\mathrm{DAA}_{\mathrm{f}}$ is low $(80 \mathrm{~g} / \mathrm{d}$, MacRae \& Ulyatt, 1974) presumably because the rapid availability of the soluble protein from the herbage is not matched by a concomitant supply of fermentable energy. This results in inefficient capture of $\mathrm{N}$ by the microbial biomass and a net loss as ammonia. With frozen clover, $\mathrm{DAA}_{\mathrm{f}}$ is similar to dietary intake $(137 \mathrm{~g} / \mathrm{d}$, Beever et al. 1971). Freezing of clover reduces protein solubility by approximately 0.5 (MacRae \& Ulyatt, 1974) and this slows degradation of dietary protein and allows a greater temporal harmony between $\mathrm{N}$ and energy availability. Microbial synthesis is then more efficient. For clover given in the dried form, $\mathrm{DAA}_{\mathrm{f}}$ is considerably greater than dietary intake ( $160 \mathrm{~g} / \mathrm{d}$, Beever et al. 1971). This 
indicates a net addition of endogenous $\mathrm{N}$ anterior to the duodenum. The endogenous input represents material from digestive proteins, cell desquamation and urea secreted into the rumen, with a variable proportion of the urea subsequently incorporated into microbial constituents. The former two processes will provide no net gain of amino acid- $\mathrm{N}$ to the system while the urea provides a 'safety-net' to recover some of the urea-N derived from rumen ammonia or tissue amino acid catabolism. These processes will inevitably contribute to $\mathrm{DAA}_{\mathrm{f}}$ even under conditions where there is a net loss of $\mathrm{N}$ between mouth and duodenum. It is thus extremely difficult to assess the true amount of amino acid- $\mathrm{N}$ available to the animal from dietary sources by the conventional procedures of measuring $\mathrm{DAA}_{\mathrm{f}}$.

Detailed study of the fate of dietary $\mathrm{N}$ in ruminants fed normally requires complicated isotope kinetic studies which involve re-entrant cannula procedures so that re-cycling of tracer to the rumen is minimized (Nolan, 1975; Siddons et al. 1985). Using such techniques with sheep given dried grass or silage supplied at energy maintenance $(\mathrm{M})$ intake, Siddons et al. (1985) observed a net loss of $\mathrm{N}$ between mouth and duodenum for silage $(19.5 \% .15 .5 \mathrm{~g} \mathrm{~N} / \mathrm{d})$ but a net gain for dried grass (II.O (NAN) was similar and approximately 0.5 of duodenal $\mathrm{N}$ flow but the proportion of this derived from urea secreted into the rumen was 0.07 for silage and 0.26 for dried grass. Similarly, endogenous non-urea- $\mathrm{N}$ entering the rumen and abomasum represented 0.19 and 0.54 respectively of intake N. The net recovery of NAN for potential tissue use was calculated as 4.3 and $3.5 \mathrm{~g} \mathrm{~N} / \mathrm{d}$ for the two diets which represents only 0.22 and 0.32 of the original dietary $\mathrm{N}$. This illustrates not only the complexity of the interactions but the severity of $\mathrm{N}$ loss under particular dietary conditions and the difficulty in predicting the amounts of dietary $\mathrm{N}$ made available for anabolic processes. So far information gathered by this type of technique has been restricted to single ration intakes and not until similar findings are obtained at different intakes will our understanding of, and thus ability to predict, the rates and controls of interconversions advance.

Amino acid uptake. The main fate of NAN entering the small intestine is proteolysis followed by absorption of the released amino acids and oligopeptides. The net disappearance of NAN across the small intestine is reasonably constant (0.65-0.80; see, for example, Clarke et al. 1966; Storm et al. 1983a) although some marked variations do occur. Thus while Siddons et al. (1985) observed a digestibility of 0.7 for microbial protein the fraction of duodenal NAN of endogenous plus dietary nature from the silage rations had a net uptake of only 0.32 while the corresponding fraction from the dried-grass diet had a value of 0.62 . For individual amino acids the situation is similar. In most studies the net absorptions of specific amino acids are greater than 0.75 (e.g. Clarke et al. ig66; Harrison et al. 1973; Storm et al. 1983 b) but occasionally lower uptakes for specific residues are reported, most notably histidine (Lindsay et al. 1980), cysteine (Clarke et al. 1966; Lindsay et al. 1980; Thomas et al. 1980) and proline (MacRae \& Ulyatt, 1974). These lower net values are thought to be due mainly to the high 
concentrations of these particular amino acids in endogenous intestinal secretions which are increased on certain diets and because particular feed proteins are associated with structural carbohydrate which reduces susceptibility to proteolytic attack (Clarke et al. 1966). Histidine is a limiting amino acid for growth in many situations (see MacRae \& Reeds, 1980; Storm \& Ørskov, 1984; MacRae \& Lobley, 1986) as is methionine; the metabolic demand on methionine would be increased by cysteine deficiency. Proline, although a non-essential amino acid, is required by the animal in much greater quantities than those supplied from the diet, so a large biosynthesis is necessary with the requirement for suitable quantities of an available $\mathbf{N}$ source.

\section{Amino acid utilization}

Increased attention will need to be focused on the supply of particular amino acids as potential limitations to protein deposition. Protein quality is as important to the ruminant as any other animal but hitherto attention to protein quality has been low because of the major contribution by bacterial protein to the amino acid supply with, in consequence, a relatively fixed pattern of amino acids available from digestion. A comparison of the amino acid composition of body protein and microbial protein (MacRae \& Reeds, 1980) indicates that, compared with lysine, there is a deficiency of several amino acids in microbial protein, i.e. methionine, histidine, arginine (plus proline and serine), so that a general increment in essential amino acids should stimulate tissue deposition. Thus it has been considered recently that a more sensible and accurate prediction of amino acid utilization might be achieved by use of the available essential amino acid fraction rather than total NAN or amino acid-N (see Smith, 1980; Agricultural Research Council, 1984). In particular conditions, however, different amino acids may become limiting. In wool growth, for example, the demand for S-amino acids is high whereas for tissue gain lysine and histidine can also become limiting (see Storm \& Ørskov, 1984; MacRae \& Lobley, 1986). The increased use of protein sources with a low rumen degradability, either as a natural feature or as a result of treatment, means that greater proportions of feed proteins can now reach the abomasum so that the composition of rumen microbial protein becomes less of a constraint to specific amino acid supply. Furthermore, it is feasible that alterations in microbial protein composition may be achieved by altering the genetic characteristics of the rumen micro-organisms by use of recombinant techniques.

From simple comparison of tissue amino acid composition (J. C. MacRae, personal communication) it can be calculated that if microbial protein is the major source of amino acids then, relative to lysine, only histidine and arginine are undersupplied for total body-protein gain and that the proportional excess of essential and non-essential amino acids is 0.19 and 0.11 respectively whereas based on histidine the excess would rise to 0.40 and 0.31 respectively. These calculations do not include the utilization of amino acids for processes other than protein deposition but would appear to set limits for the efficiency of utilization in situations where microbial protein supply is dominant. Because of the considerable 


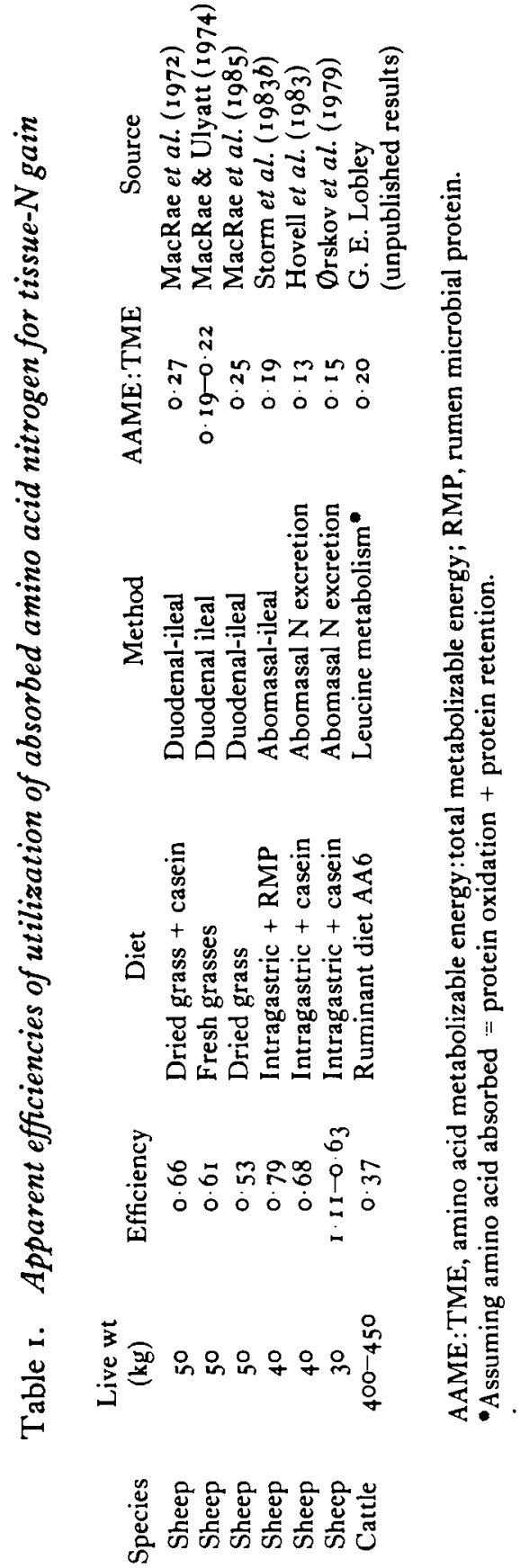




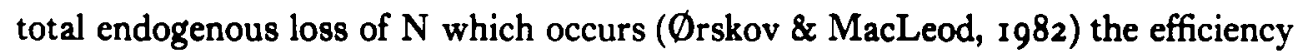
of utilization of absorbed amino acids for growth can only be determined from experiments where at least two dietary intakes have been studied in conjunction with measurements of $\mathrm{N}$ retention and amino acid absorption. There are surprisingly few such experiments reported in the literature but from these a wide range of apparent efficiencies of utilization have been detailed or can be derived (Table I). The question of whether the efficiency is constant or variable is obviously of great importance both for the development of prediction systems and for understanding the underlying mechanisms. Several possibilities exist to explain the divergent values shown in Table $\mathrm{I}$.

First, the duodenal-ileal uptake studies of MacRae and co-workers (MacRae et al. 1972, 1985; MacRae \& Ulyatt, 1974) may be affected by the supply of amino acids from preduodenal endogenous $\mathrm{N}$ sources and this would lead to an overestimate of protein derived directly or indirectly from feed and a consequent underestimate of efficiency of utilization. If, however, endogenous $\mathrm{N}$ loss does not increase with intake these values will represent a practical indication of net tissue utilization. On conventional diets, at least, $\mathrm{N}$ retention is usually overestimated by balance procedures which would increase the apparent efficiency but this type of measurement forms, in part, the basis for the present UK schemes (Agricultural Research Council, 1980 , 1984$)$. The values calculated from the values given by Storm et al. $(1983 a, b)$ appear close to the theoretical efficiencies which can be calculated based on amino acid composition. Animals maintained on complete intragastric infusion cannot re-incorporate endogenous urea into bacterial protein for resorption so even the values of Storm et al. $(1983 a, b)$ must represent an underestimate of the potential of the animal to retain $\mathrm{N}$.

Second, Ørskov et al. (1979, 1982) have tended to use young lambs while the experiments with more conventional feeding involved either older lambs or mature animals where an increased tendency to utilize amino acid-derived carbon as a source of fat may occur.

A third possibility concerns the balance between amino acid supply and available energy. Storm et al. $(1983 a)$ demonstrated, in infusion-maintained lambs, a linear relation between abomasal $\mathrm{N}$ infusion and $\mathrm{N}$ retention provided that amino acid metabolizable energy (AAME) was less than 0.19 of total metabolizable energy (TME). In many feeding situations AAME:TME apparently exceeds this (see Table I). If the protein-energy relations are similar between conventionally fed and intragastrically infused animals then, in the case of animals fed on grass, AAME:TME is potentially limiting and amino acid deposition should respond to increases in energy supply. MacRae \& Ulyatt (1974), however, found a much superior correlation for live-weight gain with protein absorption $(r 0.79)$ than with energy availability $(r 0.02)$ under conditions where AAME:TME exceeded 0.2 (see Table I). Also it has been observed that on several New Zealand herbages a positive growth response for sheep is actually achieved by adding extra protein (Barry, I98I). In growing pigs the optimal protein energy:digestible energy is probably closer to 0.26 (from Campbell et al. 1985). Obviously the interactions 
between protein gain and energy supply need to be tested further under a wider range of conditions in ruminants.

\section{Dynamics and energy costs of protein metabolism}

The relations between protein deposition and energy availability relate, in part at least, to the energy cost of protein synthesis. At present 5 mol ATP are ascribed to the cost of the processes which culminate in the production of $\mathrm{I} \mathrm{mol}$ peptide bond (Millward et al. 1976) and conventionally this is converted to $4.5 \mathrm{~kJ}$ metabolizable energy (ME)/g protein synthesized. Although several measurements, using radioactive tracers, of amino acid irreversible loss rate (ILR) and oxidation have been reported for ruminants (see Mathers \& Miller, 1979), there have been few studies of alterations in protein dynamics which occur in response to nutrient changes. Davis et al. (1981) examined the changes in plasma leucine flux, tissue synthesis rate and protein deposition in growing lambs caused by abomasal infusion of casein. The study provided no estimate of leucine catabolism, but if this is calculated as leucine intake minus leucine retention then the additional casein $(44 \mathrm{~g} / \mathrm{d} ; 25 \mathrm{mmol}$ leucine absorbed/d) increased retention and synthesis by 8 and $19 \mathrm{mmol}$ leucine/d respectively, an incremental efficiency of deposition:synthesis of 0.42 . This value is similar to the $0.4 \mathrm{I}$ obtained by Reeds et al. ( $\mathrm{rg80}$ ) from the leucine ILR of young growing pigs. Leucine metabolism in finishing beef steers followed rather different kinetics in a situation where intake was progressively reduced from 1.6 times maintenance ( $M)$ to $M$ and then to zero (fasting). The efficiency of deposition:synthesis above $\mathrm{M}$ was 0.20 (Table 2). The corresponding apparent retention of absorbed $\mathrm{N}$ was 0.36 (Table $\mathrm{I}$ ) whereas in the pigs this value was 0.75 (Reeds et al. 1980). Between fasting and $\mathrm{M}$, deposition:synthesis was higher for the steers ( 0.54 ; Table 2 ) but clearly other factors came into account as at zero and low intakes protein is used as an energy source (see Asplund et al. 1985) so at higher intakes protein is spared with an apparent and artefactual improvement in deposition:synthesis efficiency. The much reduced efficiency above $M$ again raises the question of age-related alterations in protein metabolism but clearly for ruminants our information in this area is woefully inadequate.

The values for protein synthesis given in Table 2 are minimum estimates based on blood leucine ILR measurements (see Waterlow et al. 1978; Reeds \& Lobley,

Table 2. Effect of dietary intake on leucine metabolism in beef steers*

$\begin{array}{cccccc}\text { Intake } & \begin{array}{c}\text { Live wt } \\ (\mathrm{kg})\end{array} & \begin{array}{c}\text { Protein } \\ \text { synthesis } \dagger \\ (\mathrm{g} \mathrm{N} / \mathrm{d})\end{array} & \begin{array}{c}\text { Protein } \\ \text { oxidation } \neq \\ (\mathrm{g} \mathrm{N} / \mathrm{d})\end{array} & \begin{array}{c}\text { Nitrogen } \\ \text { retention } \\ (\mathrm{g} \mathrm{N} / \mathrm{d})\end{array} & \begin{array}{c}\text { Heat } \\ \text { production } \\ (\mathrm{MJ} / \mathrm{d})\end{array} \\ \text { I.6 M } & 480 & 430 & 56 & 26 & 65 \cdot 9 \\ \text { M } & 465 & 345 & 30 & 6 & 52 \cdot 3 \\ \circ & 437 & 278 & 39 & -48 & 39 \cdot 6\end{array}$

$M$, maintenance.

-From G. E. Lobley (unpublished results), $n 8$.

theucine irreversible loss rate $\times(1-$ fractional oxidation) $\mathrm{mmol}$ leucine $/ \mathrm{h} \times 8 \cdot \mathrm{I}$.

$\ddagger$ Leucine irreversible loss rate $\times$ fractional oxidation mmol leucine $/ \mathrm{h} \times 8 \cdot \mathrm{I}$. 
1980) but even at these values the anabolic process places a significant demand on the energy status of the animal. The extra synthesis of $85 \mathrm{~g}$ protein-N/d between $M$ and $\mathrm{I} .6 \mathrm{M}$ would increase heat production by $2.4 \mathrm{MJ} / \mathrm{d}$. This represents 0.18 of the incremental heat loss which is similar to the minimum energy cost calculated for a wide range of adult species fed to $M$ and measured by similar procedures (Garlick, 1980; MacRae \& Reeds, 1980), and for the fasted steer (from Table 2; see MacRae \& Lobley, 1986). The implications of the various processes which contribute to $\mathrm{M}$ energy requirements have been considered elsewhere (MacRae \& Lobley, 1986; Milligan, 1986) but above $M$ a further unavoidable penalty will be associated with the biosynthesis of lipid. For practical reasons our information on rates of ruminant lipid metabolism in vivo is almost non-existent but the theoretical costs of fatty acid synthesis can be calculated from the stoichiometry of the biochemical reactions. Thus for ruminants producing fat from acetate, and deriving ATP, glycerol and $\mathrm{NADPH}_{2}$ from glucose (with propionate as precursor), synthesis of I MJ fat would have an associated heat loss of $0.32 \mathrm{MJ}$ (from Baldwin, 1968; Milligan, 1971). If lipid turnover is assumed to be minimal then the energy cost of fat synthesis will be similar to the cost of fat deposition. Thus if this calculated value is applied to the fat deposition calculated from energy-balance measurements made on the steers described in Table 2, and the energy cost of the measured (minimum) protein synthesis is added, the amount of heat production expected between $M$ and $1.6 \mathrm{M}$ would be 0.27 of the ME increment (Table 3 ). In practice a value of 0.45 in incremental heat loss was observed. In contrast, for growing pigs, assuming an efficiency of synthesis of fat from glucose of 0.85 (Millward et al. 1976), 0.85 of the heat increment observed by Reeds et al. (1980) can be explained by the minimum biochemical costs of protein and fat synthesis (Table 3).

\section{Thermal losses associated with digestive processes}

The values for cattle presented in Table 3 are typical of those obtained in many studies in ruminant nutrition in that retention of energy above $M$ intake $\left(k_{f}{ }^{\prime}\right)$ is lower than would be expected from the metabolic energy requirements of the anabolic processes (see Blaxter \& Boyne, 1978). The increased thermal losses are greater with roughage diets than with concentrate-based diets. It has been suggested that the fibrous nature of dried roughages increases the energy costs of digestion by an enhanced secretion of salts in digestive fluids, such as saliva, and of enzymes, bile, mucin, etc., accompanied by a greater desquamation through physical action. These secretions and losses will involve considerable synthetic activity and replacement costs. In terms of protein costs the magnitude of these effects have been estimated variously as $20-200 \mathrm{~g} / \mathrm{d}$ (see e.g. McDougall, I 966 ; Fauconneau \& Michel, 1970). This could represent at least $0.1-0.6$ of total body protein synthesis (see Lobley et al. 1980; Davis et al. 1981) which, based on an energy cost of $4.5 \mathrm{~kJ} / \mathrm{g}$, would add $0.09-0.9 \mathrm{MJ} / \mathrm{d}$ to energy expenditure. In order to account totally for a change in heat increment from, say, 0.35 to 0.6 these additional secretions would need to be doubled or trebled as a result of different 


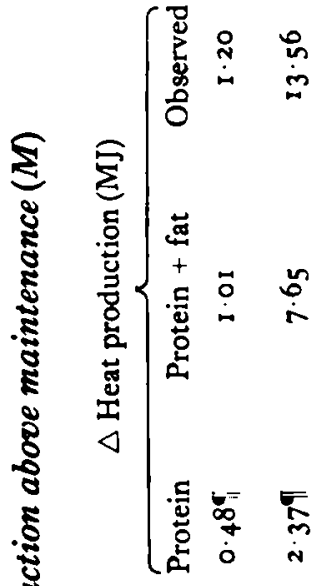

5

政

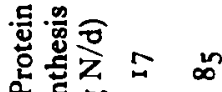

ปี

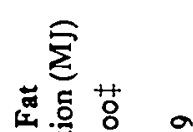


dietary treatments. Direct and indirect comparisons do not provide consistent support for increases of this magnitude. For example, Webster ( 1980 ) concluded that only half of increased thermal losses were associated with gastrointestinaltract-related processes. This was despite the considerable metabolic activity of this tissue, $0.25-0.33$ of total aerobic energy expenditure (Webster, 1980) and $0.32-0.46$ of whole-body protein synthesis (Lobley et al. 1980). Comparison of total protein synthesis in dry cows offered $M$ intakes either as intragastric infusion $\left(2.5 \mathrm{~g}\right.$ protein $\mathrm{N} / \mathrm{kg}$ live weight ${ }^{0.75}$ per $\mathrm{d}$; Reeds \& Orskov, 1981) or as concentrate-straw mixture $\left(2.2 \mathrm{~g}\right.$ protein $\mathrm{N} / \mathrm{kg}$ live weight ${ }^{0.75}$ per $\mathrm{d}$; Lobley et al. 1980) does not, however, indicate a marked increase in response to additional secretion of digestive proteins when more fibrous diets are offered. In contrast, growing steers maintained on a barley straw ration (Table 2) had a whole-body synthetic rate $0.3^{8}$ greater than the mature females at $M$ on intragastric nutrition but whether this difference represents enhanced digestive activity is not known.

A further consequence of increased secretions of gut protein would be an increased endogenous loss as material is not totally reabsorbed from the tract. Estimates of net endogenous amino acid loss through the small intestine can be obtained from incremental studies by regression of duodenal supply and amino acid uptake. For infusion-maintained sheep (Storm et al. $1983 b$ ) the daily value was $20 \mathrm{mg}$ amino acid-N/ $\mathrm{kg}$ live weight ${ }^{0.75}$. When incremental additions of casein were made to a forage ration the corresponding estimate was $29 \mathrm{mg} \mathrm{N} / \mathrm{kg}^{0.75}$ (from MacRae et al. 1972) while corresponding analysis with different intakes of herbage indicated a loss of $94 \mathrm{mg} \mathrm{N} / \mathrm{kg}$ live weight ${ }^{0.75}$ (from MacRae \& Ulyatt, 1974). In the latter two studies the corresponding apparent efficiencies of total amino acid absorption were between 0.72 and 0.79 and if endogenous protein was reabsorbed to a similar extent then, compared with the infusion-maintained animals, possibly 5-50 $\mathrm{g}$ extra amino acid could be secreted into the lumen of the small intestine in response to nutrient input changes. Of course it is not strictly correct to apply simple regressions of this nature to increased intake as the probable effect will be to underestimate both absorption rates and net endogenous loss and indeed the latter could be solved as a negative, i.e. apparent uptake occurs.

Probably only part of the heat loss and inefficiencies of $\mathrm{N}$ retention can be attributable to specific effects of gastrointestinal function (see Webster, 1980) but the possible necessity for inclusion of a 'digestion factor' in future prediction systems would present considerable difficulty.

\section{Thermal losses associated with other protein-energy interactions}

The effects of different types of energy substrates on $\mathrm{N}$ metabolism have been shown by Eskeland et al. (1973) who examined the effects of intravenous infusion of glucose, propionate, butyrate and acetate on protein deposition in lambs fed on poor-quality diets based on cottonseed meal. In five different experiments they found repeatedly that improvement in $\mathbf{N}$ retention was greatest with glucose, then propionate and butyrate and lastly acetate. In fact although the exogenous additions were isoenergetic $(2 \mathrm{MJ} / \mathrm{d})$ there are slight differences in the theoretical 
yields of $A T P / M J M E ~(13 \cdot 2,12 \cdot 3,11 \cdot 7,11 \cdot 4 \mathrm{~mol} / \mathrm{MJ}$ respectively). If the supply of ATP were limiting protein synthesis then the difference in biochemical energy between glucose and acetate $(3.6 \mathrm{~mol} \mathrm{ATP} / \mathrm{d})$ would fuel the synthesis of approximately $70 \mathrm{~g}$ protein which at a deposition efficiency of 0.2 (Table 2) would represent an improvement in $\mathrm{N}$ retention of $2.2 \mathrm{~g} \mathrm{~N} / \mathrm{d}$. Eskeland et al. (1973) actually observed differences in $\mathrm{N}$ retention between glucose and acetate infusions of $1.3-2.8 \mathrm{~g} \mathrm{~N} / \mathrm{d}$. The situation may be more complicated, however, than simple energy availability. Recently Lobley \& MacRae (1986) infused, per abomasum, either acetate or propionate $(1 \cdot 75 \mathrm{MJ} / \mathrm{d})$ to sheep fed on grass cubes of good quality (high-soluble carbohydrate, high $\mathrm{N}$ ) at $\mathrm{I} \cdot 5 \mathrm{M}$. As a result of acetate (but not propionate) infusion the sheep went into negative $\mathrm{N}$ retention $(-2 \mathrm{~g} \mathrm{~N} / \mathrm{d}$; saline ( 9 g sodium chloride/l)-infused controls $+5 \mathrm{~g} \mathrm{~N} / \mathrm{d}$ ). Similarly, Girdler et al. (1986) observed, with infusion-maintained sheep, that while glucose or propionate caused positive responses in $\mathrm{N}$ retention, acetate produced a negative effect which could be mitigated by infusion of glucose. This was achieved in an experimental situation where AAME:TME was approximately 0.15 and thus $\mathrm{N}$ retention would not be limited by energy input (from Storm et al. 1983a,b). These findings are consistent with a hypothesis advanced by several authors (for reviews, see MacRae \& Lobley, 1982, 1986) that efficient utilization of acetate for fat synthesis can only proceed if adequate supplies of $\mathrm{NADPH}_{2}$ and glycerol are provided and, in the ruminant, these are derived primarily from glucose. In the forage-fed ruminant glucose needs to be synthesized de novo from precursors (propionate, lactate, glucogenic amino acids), so under conditions where absorption or supply of propionate and lactate is low, while that of acetate is high, conversion of the latter to fatty acids can only proceed at the expense of conversion of glucogenic amino acids with a consequent penalty on protein economy.

In situations where amino acid supply is either restricted or has its availability limited by other metabolic considerations, acetate cannot be completely utilized and as a consequence substrate cycles (futile cycles) are stimulated to effect an energy loss. Several substrate cycles are known to exist (Rabkin \& Blum, 1985) and there is evidence that one, the acyl-CoA hydrolase reaction, operates in ruminant muscle (Pethick et al. 1981; B. Crabtree, personal communication).

Practical effects of protein supply and diet quality on energy utilization have been shown in calorimetric studies. For example, MacRae et al. (1985) showed an improvement in $\boldsymbol{k}_{f}{ }^{\prime}$ as a result of abomasal infusion of casein to sheep offered poor-quality autumn-harvested dried grass although no increase in $\mathrm{N}$ retention was observed. Similarly, Lobley \& MacRae (1986) infused, intravenously, sodium acetate $(2 \mathrm{~mol} / \mathrm{d})$ to sheep given $M$ rations of two different quality diets. When presented with grass cubes, high in both $\mathrm{N}$ and soluble carbohydrate, the apparent heat increment of the exogenous acetate was 0.34 , a value close to that observed in trials with infusion-maintained sheep supplied a high-protein mixture (protein energy 0.23 TME; Ørskov et al. 1979). When fed on a low N (<20 g N/kg dry matter), low soluble-carbohydrate grass the heat increment was approximately 0.6 .

If amino acids have a significant glucogenic role in runinant metabolism then 
under certain dietary conditions of low amino acid supply and high acetate absorption there will be a double penalty, i.e. both $\mathrm{N}$ and energy retention will be decreased.

Clearly at several levels protein and energy substrates both interact and intersubstitute. Simple factorial predictions will not be adequate to account for these metabolic complexities so more dynamic schemes will be necessary. To produce and test these new developments will require experimentation which concentrates on incremental or response analyses. The challenges faced by those interested in ruminant nutrition and metabolism are greater than those in 'simple-stomach' research but so is the satisfaction!

\section{REFERENCES}

Agricultural Research Council (1980). The Nutrient Requirements of Ruminant Livestock. Slough: Commonwealth Agricultural Bureaux.

Agricultural Research Council (1984). The Nutrient Requirements of Ruminant Livestock, Suppl. No I. Slough: Commonwealth Agricultural Bureaux.

Asplund, J. M., Ørskov, E. R., Hovell, F. D. DeB. \& MacLeod, N. A. (1985). British Fournal of Nutrition 54, 189-195.

Baldwin, R. L. (1968). Fournal of Dairy Science 51 , 104-1 I 1 .

Barry, T. N. (1981). British Journal of Nutrition 46, $521-532$.

Beever, D. E., Thomson, D. J. \& Harrison, D. G. (197I). Proceedings of the Nutrition Society 30, $86 \mathrm{~A}$.

Blaxter, K. L. \& Boyne, A. W. (1978). Fournal of Agricultural Science, Cambridge 90, 47-68.

Campbell, R. G., Taverner, M. R. \& Curic, D. M. (I985). Animal Production 40, 489-496.

Clarke, E. M. W., Ellinger, G. M. \& Phillipson, A. T. (1966). Proceedings of the Royal Society B $166,63-79$.

Davis, S. R., Barry, T. N. \& Hughson, G. A. (1981). British fournal of Nutrition 46, 409-419.

Eskeland, B., Pfander, W. H. \& Preston, R. L. (1973). British fournal of Nutrition 29, 347-355.

Fauconneau, G. \& Michel, M. C. (1970). In Mammalian Protein Metabolism, vol. 4, pp. 481-522 [H. N. Munro, editor]. New York: Academic Press.

Garlick, P. J. (1980). In Protein Deposition in Animals, pp. 51-68 [P. J. Buttery and D. B. Lindsay, editors]. London: Butterworths.

Girdler, C. P., Thomas, P. C. \& Chamberlain, D. G. (1986). Proceedings of the Nutrition Society 45, $43 \mathrm{~A}$.

Harrison, D. G., Beever, D. E., Thomson, D. J. \& Osbourn, D. F. (1973). Fournal of Agricultural Science, Cambridge 81, 391-401.

Hovell, F. D. DeB., Orskov, E. F., MacLeod, N. A. \& McDonald, I. (1983). British fournal of Nutrition 50, $33^{1-343}$.

Lindsay, J. R., Hogan, J. P. \& Donnelly, J. B. (1980). Australian Journal of Agricultural Research 31, 589-600.

Lobley, G. E. \& MacRae, J. C. (1986). In Proceedings roth Energy Metabolism Symposium, Virginia, USA (In the Press).

Lobley, G. E., Milne, V., Lovie, J. M., Reeds, P. J. \& Pennie, K. (1980). British fournal of Nutrition 43, 491-502.

McDougall, E. I. (1966). Biochemical fournal 100, 19-26.

MacRae, J. C. \& Lobley, G. E. (I982). Livestock Production Science 9, 447-456.

MacRae, J. C. \& Lobley, G. E. (1986). The 6th International Symposium on Ruminant Physiology, Banff, Canada (In the Press).

MacRae, J. C. \& Reeds, P. J. (1980). In Protein Deposition in Animals, pp. 225-249 [P. J. Buttery and D. B. Lindsay, editors]. London: Butterworths.

MacRae, J. C., Smith, J. S., Dewey, P. J. S., Brewer, A. C., Brown, D. S. \& Walker, A. (1985). British Journal of Nutrition 54, 197-209. 
MacRae, J. C. \& Ulyatt, M. J. (1974). Fournal of Agricultural Science, Cambridge 82, 309-319.

MacRae, J. C., Ulyatt, M. J., Pearce, P. D. \& Hendtlass, J. (1972). British fournal of Nutrition 27, $39-50$.

Mathers, J. C. \& Miller, E. L. (1979). In Protein Metabolism in the Ruminant, pp. 3.I-3.I I [P. J. Buttery, editor]. London: Agricultural Research Council.

Milligan, L. P. (1971). Federation Proceedings 30, 1454-1458.

Milligan, L. P. (1986). Proceedings of the Nutrition Society 45, $185-193$.

Millward, D. J., Garlick, P. J. \& Reeds, P. J. (1976). Proceedings of the Nutrition Society 35, $339-349$.

Nolan, J. V. (1975). In Digestion and Metabolism in the Ruminant, pp. 416-431 [1. W. McDonald and A. C. I. Warner, editors]. Armidale, Australia: University of New England Publishing Unit.

Ørskov, E. R., Grubb, D. A., Smith, J. S., Webster, A. J. F. \& Corrigall, W. (1979). British Fournal of Nutrition 4I, 541-551.

Ørskov, E. R. \& MacLeod, N. A. (1982). British fournal of Nutrition 47, 625-636.

Pethick, D. W., Lindsay, D. B., Barker, P. J. \& Northrop, A. J. (1981). British Fournal of Nutrition 46, 97-1 10.

Rabkin, M. \& Blum, J. J. (1985). Biochemical fournal 225, 761-786.

Reeds, P. J., Cadenhead, A., Fuller, M. F., Lobley, G. E. \& McDonald, J. D. (1980). British fournal of Nutrition 43, 445-455.

Reeds, P. J. \& Lobley, G. E. (1980). Proceedings of the Nutrition Society 39, 43-52.

Reeds, P. J. \& Ørskov, E. R. (1981). Proceedings of the Nutrition Society 40, 50 A.

Siddons, R. C., Nolan, J. V., Beever, D. E. \& MacRae, J. C. (1985). British fournal of Nutrition $54,175-187$.

Smith, R. H. (1980). Proceedings of the Nutrition Society 39, 71-78.

Storm, E., Brown, D. S. \& Ørskov, E. R. (1983b). British fournal of Nutrition 50, 479-485.

Storm, E. \& Ørskov, E. R. (1984). British fournal of Nutrition 52, 61 3-620.

Storm, E., Ørskov, E. R. \& Smart, R. (1983a). British fournal of Nutrition 50, $471-478$.

Thomas, P. C., Chamberlain, D. G., Kelly, N. C. \& Wait, M. K. (1980). British fournal of Nutrition 43, 469-479.

Waterlow, J. C., Garlick, P. J. \& Millward, D. J. (1978). Protein Turnover in Mammalian Tissues and in the Whole Body. Amsterdam: Elsevier, North Holland.

Webster, A. J. F. (1980). In Digestive Physiology and Metabolism in Ruminants, pp. 469-484 [Y. Ruckebusch and P. Thivend, editors]. Lancaster: MTP Press. 